\title{
PROFIL PENGUASAAN MATERI MATEMATIKA SEKOLAH MAHASISWA PENDIDIKAN MATEMATIKA SEMESTER VI
}

\author{
Marfi Ario \\ Universitas Pasir Pengaraian \\ Email: marfi.ario.92@gmail.com
}

\begin{abstract}
Each teacher is required to have pedagogic, personality, professional, and social competence. Professional competence refers to the ability of mastery of learning materials widely and deeply that enables to guide learners meet the established competency standards. Based on this, every mathematics teacher candidate must have good mastery of school mathematic materials. This study aims to determine the profile of mastery of school mathematics materials students of mathematics education program semester VI. It is important to know the readiness of students to become professional math teachers. This research is a descriptive research. The study sample consisted of 2 classes with 48 students. Data collected through the test. The test results were analyzed using descriptive statistics. The results showed that the mastery of mathematics materials of students school semester VI is very low at 22.5\%. This indicates that students as math teacher candidates do not have professional competence. The results of this study is expected to be a source of information for stakeholders to develop learning and curriculum that are able to prepare students who are competent in mastery of school mathematics materials.
\end{abstract}

Keywords: professional competence, school mathematics materials, student of mathematics education

\section{PENDAHULUAN}

Kemajuan suatu bangsa salah satunya dipengaruhi oleh kualitas pendidikannya. Berbicara tentang pendidikan maka tidak terlepas dari pembicaraan tentang guru. Guru adalah sosok yang membimbing dan mendidik peserta didik untuk menjadi pribadi yang cerdas dan berakhlak. Untuk terciptanya peserta didik yang berkualitas, maka diperlukan guru yang berkualitas pula.

Menurut UU Nomor 14 Tahun 2005 seorang guru harus memiliki empat kompetensi, yaitu kompetensi pedagogik, kepribadian, professional, dan sosial. Kompetensi pedagogik adalah kemampuan mengelola pembelajaran peserta didik yang meliputi pemahaman terhadap peserta didik, perancangan, dan pelaksanaan pembelajaran, evaluasi hasil belajar, dan mengembangkan peserta didik dalam mengaktualisasi potensi dirinya. Kompetensi kepribadian adalah kemampuan kepribadian yang mantap, stabil, dewasa, arif, dan berwibawa, menjadi teladan peserta didik, dan berakhlak mulia. Kompetensi profesional merupakan kemampuan penguasaan materi pembelajaran secara luas dan mendalam yang memungkinkan pendidik untuk membimbing peserta didik memenuhi standar kompetensi yang ditetapkan dalam standar nasional pendidikan. Kompetensi sosial adalah kemampuan pendidik sebagai bagian dari 
masyarakat untuk berkomunikasi dan bergaul secara efektif dengan peserta didik, sesama pendidik dan masyarakat sekitar.

UU Nomor 14 Tahun 2005 secara jelas menyatakan bahwa kompetensi profesional terkait dengan penguasaan materi bidang ilmu yang diambil oleh calon guru. Hal ini dipertegas lagi dalam Permendiknas Nomor 16 Tahun 2007 yang menyatakan bahwa seorang guru mata pelajaran di SMP dan SMA harus memiliki kompetensi profesional, yang salah satunya ialah menguasai materi, struktur, konsep, dan pola pikir keilmuan yang mendukung mata pelajaran yang diampu. Sedangkan Marhamah (2016) memperjelas bahwa kompetensi professional merupakan kemampuan yang berkenaan dengan penguasaan materi pembelajaran bidang studi secara luas dan mendalam yang mencakup penguasaan substansi isi materi kurikulum mata pelajaran di sekolah dan substansi keilmuan yang menaungi materi kurikulum tersebut serta menambah wawasan keilmuan bagi guru. Keberadaan guru matematika yang profesional merupakan kunci penting keberhasilan pendidikan matematika di Indonesia (Abdullah, 2015).

Berdasarkan penjelasan di atas, untuk menjadi guru matematika yang memiliki kompetensi profesional maka mahasiswa calon guru matematika harus menguasai materi-materi matematika sekolah dengan baik. Berdasarkan Permendiknas Nomor 21 Tahun 2016, ruang lingkup materi tingkat SMP adalah: Bilangan Rasional; Aljabar (pengenalan); Geometri (termasuk transformasi); Statistika dan Peluang; Himpunan; Aljabar; Geometri (termasuk bangun tidak beraturan); Statistika dan Peluang (termasuk metode statistik sederhana). Sedangkan ruang lingkup materi matematika tingkat SMA adalah Bilangan Real; Aljabar; Geometri dan Transformasi; Dasar-dasar Trigonometri; Limit fungsi Aljabar; Matriks; Kombinatorika; Statistika dan Peluang; Turunan Fungsi Aljabar; Program Linear; Geometri Ruang; Bunga Majemuk, Angsuran, Anuitas; Pertumbuhan dan Peluruhan; Matriks dan Vektor; Induksi matematika; Integral; Logika.

Berdasarkan hasil observasi pada program studi pendidikan matematika, masih ditemukan banyak mahasiswa yang tidak menguasai materi matematika sekolah dengan baik. Beberapa diantaranya yaitu mahasiswa ketika ujian komprehensif tidak mengetahu jenis-jenis bilangan dengan tepat, mahasiswa tidak mengetahui rumus luas bangun-bangun datar, mahasiswa tidak bisa melakukan penjumlahan bilangan pecahan, mahasiswa tidak mengenal perbedaan diagonal bidang dan bidang diagonal, serta tidak mampu menyelesaikan soalsoal matematika sekolah. Selain ketika ujian komprehensif, saat melakukan ujian Praktek Pengalaman Lapangan (PPL), sering juga ditemukan mahasiswa yang mengajarkan materi dengan konsep yang salah.

Temuan yang diperoleh tersebut juga senada dengan beberapa penelitian yang telah ada. Penelitian oleh Masril, Akmam dan Irvan (2013), Pakaya (2014), dan Hindarto, Wijayanto dan Sugiyanto (2016) disimpulkan bahwa penguasaan materi-materi dasar mahasiswa masih dibawah 50\%. Sedangkan penelitian oleh Maryono (2016) menyatakan bahwa penguasaan konten mahasiswa matematika dengan akademik cukup berada pada level 0 : tidak mampu menyatakan definisi dengan benar, tidak mampu menggunakan notasi dengan tepat, hanya menggunakan pertanyaan deklaratif atau prosedural, tidak mampu 
menginterpretasikan dan menggunakan representasi yang berbeda dengan mudah, kesulitan ketika melihat koneksi antara topik yang berbeda. Sedangkan mahasiswa dengan akademik yang sangat baik dan baik berada pada level 1: menyatakan definisi dengan tepat, menggunakan notasi dengan tepat, masih menggunakan pertanyaan deklaratif atau prosedural, menginterpretasikan dan menggunakan representasi grafik dan selain grafik, melihat koneksi antara topik yang berbeda. Tidak ada mahasiswa yang mencapai level 2 sebagai level tertinggi.

Mengamati hal tersebut, upaya untuk mengungkap profil penguasaan materi matematika sekolah yang dimiliki oleh calon guru matematika mendesak untuk dilakukan. Khususnya pada mahasiswa semester VI yang akan melakukan praktek mengajar di sekolah. Melalui profil penguasaan materi matematika sekolah mahasiswa yang diperoleh dapat menjadi masukan bagi program studi yang bersangkutan untuk melakukan upaya tertentu dalam mempersiapkan mahasiswa dengan penguasaan materi matematika sekolah yang lebih baik. Dengan demikian, tujuan spesifik yang ingin dicapai dalam penelitian ini adalah untuk mengetahui gambaran tentang penguasaan materi matematika sekolah pada mahasiswa pendidikan matematika semester VI.

\section{METODE PENELITIAN}

Penelitian ini bersifat penelitian deskriptif karena penelitian ini bertujuan mendeskripsikan dan menginterpretasikan data mengenai penguasaan materi matematika sekolah mahasiswa semester VI. Subyek penelitian ini adalah mahasiswa Pendidikan Matematika semester VI
Tahun Ajaran 2016/2017. Penelitian dilakukan pada Tahun 2017 di Universitas Pasir Pengaraian.

Teknik yang digunakan dalam mengumpulkan data berupa teknik tes. Instrumen tes berupa soal-soal isian pendek yang mengukur kemampuan materi matematika sekolah. Tes terdiri dari 20 soal Sekolah Menengah Pertama (SMP) dan 20 soal Sekolah Menengah Atas (SMA). Soal dibuat berdasarkan Standar Kelulusan yang ditetapkan pada kurikulum 2013 dengan mengacu kepada kisi-kisi Ujian Nasional tahun ajaran 2016/2017. Soal yang dijadikan sebagai alat tes dibuat semirip mungkin dengan Ujian Nasional (UN) tahun sebelumnya, sehingga validitas dan reliabilitas tes tidak perlu diuji lagi.

Data hasil tes penguasaan materi matematika sekolah dianalisis menggunakan statistik deskriptif. Data yang diperoleh disajikan dalam bentuk tabel dan grafik sehingga diperoleh gambaran yang jelas mengenai rata-rata, persentase, dan sebagainya. Analisis dilakukan untuk melihat lebih detail tentang penguasaan materi matematika sekolah mahasiswa.

\section{HASIL PENELITIAN DAN PEMBAHASAN}

Tes tertulis tentang penguasan materi matematika sekolah diberikan kepada mahasiswa semester VI yang terdiri dari dua kelas, yaitu kelas Reguler dan Non Reguler dengan banyak mahasiswa masing-masing 26 dan 22 orang. Data hasil tes tersebut disajikan pada Tabel 1 dan Grafik 1 . Data yang disajikan merupakan skor tes penguasaan materi matematika sekolah yang telah dikonversi dengan rentang nilai 0-100. 
ISSN 2089-8703 (Print) Vol. 6, No. 3 (2017)

ISSN 2442-5419 (Online)

Tabel 1. Deskripsi Data Penguasaan Materi Matematika Sekolah

\begin{tabular}{|c|l|c|c|c|}
\hline $\begin{array}{c}\text { Ukuran } \\
\text { Statistik }\end{array}$ & \multicolumn{1}{|c|}{$\begin{array}{c}\text { Jenjang } \\
\text { Sekolah }\end{array}$} & $\begin{array}{c}\text { Kelas } \\
\text { Reguler }\end{array}$ & $\begin{array}{c}\text { Kelas } \\
\text { Non Reguler }\end{array}$ & Gabungan \\
\hline \multirow{4}{*}{ Rata-rata } & SMP & 40,00 & 24,77 & 33,02 \\
\cline { 2 - 5 } & SMA & 16,35 & 6,82 & 11,98 \\
\cline { 2 - 5 } & Gabungan & 28,17 & 15,80 & $\mathbf{2 2 , 5 0}$ \\
\hline \multirow{2}{*}{$\begin{array}{c}\text { Simpangan } \\
\text { Baku }\end{array}$} & SMP & 24,37 & 17,83 & 22,73 \\
\cline { 2 - 5 } & SMA & 15,46 & 7,80 & 13,32 \\
\cline { 2 - 5 } & Gabungan & 18,26 & 11,19 & $\mathbf{1 6 , 5 0}$ \\
\hline \multirow{3}{*}{ Nilai Minimum } & SMP & 0,00 & 0,00 & 0,00 \\
\cline { 2 - 5 } & SMA & 0,00 & 0,00 & 0,00 \\
\cline { 2 - 5 } & Gabungan & 2,50 & 0,00 & $\mathbf{0 , 0 0}$ \\
\hline \multirow{3}{*}{$\begin{array}{c}\text { Nilai } \\
\text { Maksimum }\end{array}$} & SMP & 90,00 & 60,00 & 90,00 \\
\cline { 2 - 5 } & SMA & 55,00 & 35,00 & 55,00 \\
\cline { 2 - 5 } & Gabungan & 72,50 & 40,00 & $\mathbf{7 2 , 5 0}$ \\
\hline
\end{tabular}

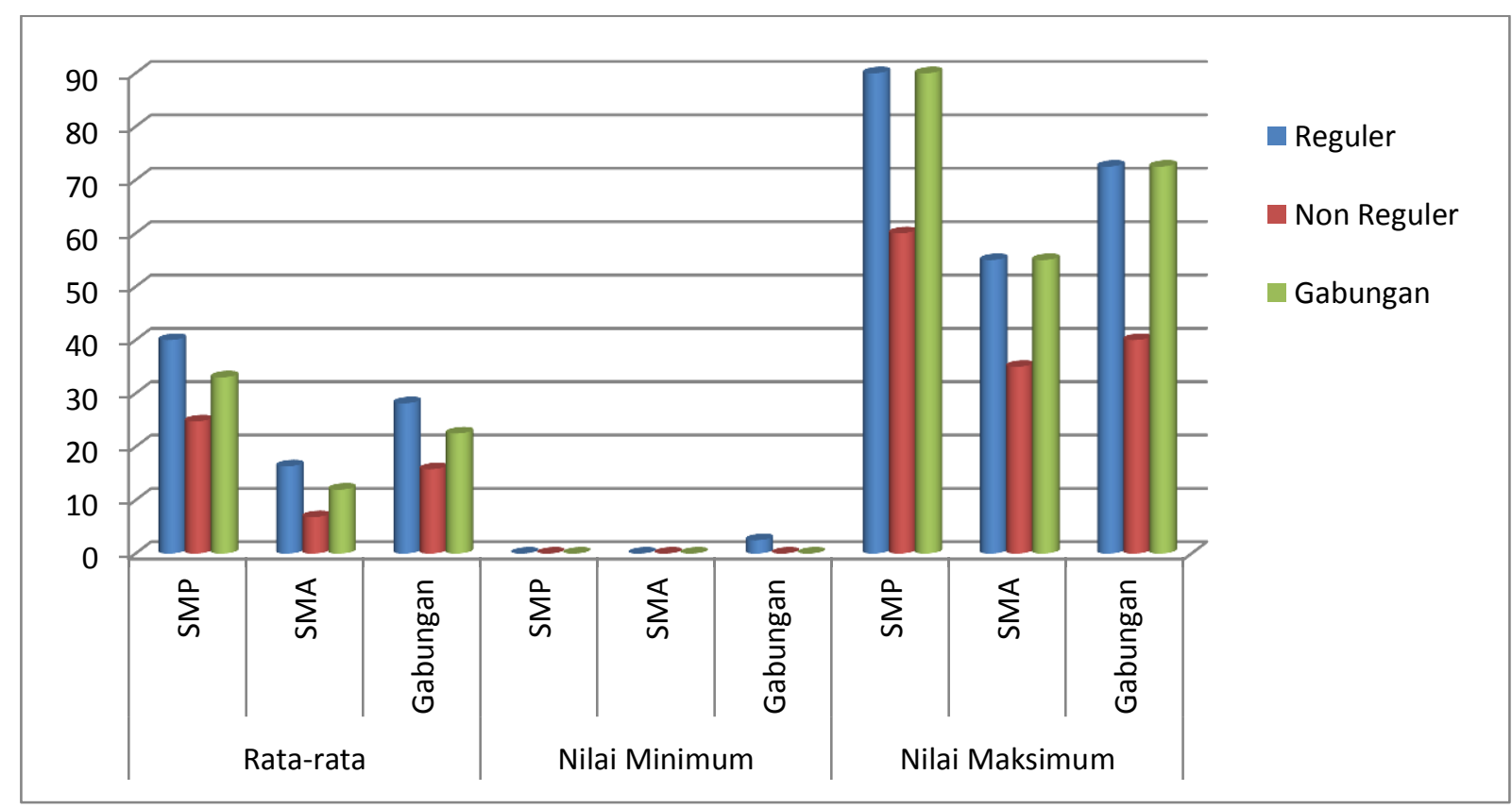

Grafik 1. Data Penguasaan Materi Matematika Sekolah

Berdasarkan data pada Tabel 1 dan Grafik 1 diketahui bahwa penguasaan materi matematika untuk jenjang SMP lebih baik dibandingkan jenjang SMA. Secara keseluruhan penguasaan materi SMP berbanding SMA adalah 33 berbanding 12. Hal ini dapat dimaklumi karena materi matematika SMP memang lebih mudah dibandingkan materi matematika SMA. Namun demikian, meskipun materi SMP tergolong mudah, berdasarkan data nilai minimum diketahui bahwa ada mahasiswa yang tidak bisa 
menjawab satu soalpun materi SMP. Begitu juga dengan materi SMA. Sehingga, ada mahasiswa yang penguasaan materi matematika sekolahnya $0 \%$.

Nilai maksimum yang berhasil dicapai mahasiswa untuk materi SMP adalah 90 dan untuk materi SMA yaitu 55. Hal ini menunjukkan bahwa tidak ada satupun mahasiswa yang memperoleh nilai yang baik pada materi SMA. Ketidakmampuan mahasiswa dalam menyelesaikan soal-soal materi SMA salah satunya disebabkan karena kurangnya penguasaan mahasiswa terhadap materi prasyarat. Materi prasyarat untuk materi SMA adalah materi-materi matematika di tingkat SMP. Berdasarkan data pada Tabel 1 diketahui bahwa penguasaan materi SMP mahasiswa hanya $33,02 \%$. Sehingga penguasaan yang kurang pada materi SMP akan berimbas pada kesulitan memahami materi SMA. Hal ini disebabkan karena matematika merupakan ilmu yang hierarki (berjenjang), yaitu konsep pada materi sebelumnya akan digunakan dan diterapkan pada materi berikut (Romadiastri, 2012). $\begin{array}{lrrr}\text { Dari } & \text { Tabel } 1 \text { dan } & \text { Grafik } 1 \\ \text { diketahui juga bahwa tingkat } \\ \text { penguasaan }\end{array}$ mahasiswa kelas Reguler lebih baik dibandingkan kelas Non Reguler. Pada materi SMP, penguasaan materi mahasiswa kelas Reguler unggul 15\% sedangakan pada materi SMA unggul 9\%. Hal ini kemungkinan disebabkan mahasiswa kelas Non Reguler sebagian besar adalah mahasiswa yang sudah bekerja. Sehingga waktu mereka untuk belajar tidak lagi sebanyak mahasiswa reguler. Selain itu, jadwal belajar mahasiswa kelas non reguler yang lebih padat dibandingkan mahasiswa reguler juga diperkirakan menyebabkan penguasaan materi mereka lebih rendah.

Jika nilai kedua kelas digabungkan, maka secara keseluruhan, rata-rata penguasaan materi matematika sekolah (SMP dan SMA) mahasiswa pendidikan matematika semester VI adalah $22,50 \%$. Hal ini menunjukkan bahwa penguasaan materi matematika sekolah mahasiswa sangat rendah.

Persebaran nilai tes penguasaan materi matematika sekolah mahasiswa semester VI dapat dilihat pada Tabel 2 berikut.

Tabel 2. Persebaran Nilai Tes

\begin{tabular}{|c|c|c|c|}
\hline \multirow{2}{*}{ Interval Nilai } & \multicolumn{3}{|c|}{ Frekuensi } \\
\cline { 2 - 4 } & SMP & SMA & Gabungan \\
\hline $0,00-25,00$ & 22 & 42 & 28 \\
\hline $25,01-50,00$ & 15 & 4 & 17 \\
\hline $50,01-75,00$ & 9 & 2 & 2 \\
\hline $75,01-100,00$ & 2 & 0 & 1 \\
\hline
\end{tabular}

Berdasarkan Tabel 2 diketahui bahwa dari 48 orang mahasiswa, hanya ada dua $(4,17 \%)$ mahasiswa yang menguasai lebih dari $75 \%$ materi SMP. Sedangkan untuk materi SMA tidak ada mahasiswa yang menguasai materi lebih dari $75 \%$. Secara keseluruhan, hanya ada $1 \quad(2,08 \%)$ mahasiswa yang memiliki penguasaan materi matematika sekolah lebih dari $75 \%$. Sedangkan $45 \quad(93,75 \%)$ mahasiswa hanya menguasai maksimal $50 \%$ materi matematika sekolah. Lebih dari separuh mahasiswa hanya memiliki penguasaan 
ISSN 2089-8703 (Print) Vol. 6, No. 3 (2017)

ISSN 2442-5419 (Online)

materi matematika sekolah pada rentang 0-25\%. Angka ini menunjukkan bahwa sebagian besar mahasiswa tidak memiliki penguasaan materi matematika sekolah yang memadai.

Tabel 3 dan Tabel 4 berikut ini akan memperlihatkan penguasaan materi matematika sekolah pada masing-masing materi. Hal ini dilakukan untuk mengetahui lebih jauh pada materi apa paling banyak mahasiswa bermasalah.

Tabel 3. Penguasaan Materi SMP

\begin{tabular}{|c|l|l|}
\hline Bidang & \multicolumn{1}{|c|}{ Lingkup Materi } & Penguasaan (\%) \\
\hline \multirow{4}{*}{ Bilangan } & Operasi bilangan bulat, pecahan, pangkat, dan akar & 37,50 \\
\cline { 2 - 3 } & Perbandingan & 45,83 \\
\cline { 2 - 3 } & Pola barisan bilangan & 27,08 \\
\hline \multirow{4}{*}{ Aljabar } & Persamaan dan pertidaksamaan linear satu variabel & 31,25 \\
\cline { 2 - 3 } & Himpunan & 36,46 \\
\cline { 2 - 3 } & Relasi atau fungsi & 47,92 \\
\cline { 2 - 3 } & Persamaan garis lurus & 8,33 \\
\cline { 2 - 3 } & Sistem persamaan linear dua variabel & 50,00 \\
\hline \multirow{4}{*}{$\begin{array}{c}\text { Geometri } \\
\text { pengukuran }\end{array}$} & Garis dan sudut & 31,25 \\
\cline { 2 - 3 } & Segiempat dan segitiga & 16,67 \\
\cline { 2 - 3 } & Teorema Pythagoras & 33,33 \\
\cline { 2 - 3 } & Lingkaran & 54,17 \\
\cline { 2 - 3 } & Bangun ruang sisi datar & 43,75 \\
\cline { 2 - 3 } & Kesebangunan dan kekongruenan & 4,17 \\
\hline \multirow{3}{*}{$\begin{array}{c}\text { Statistika } \\
\text { dan } \\
\text { peluang }\end{array}$} & $\begin{array}{l}\text { Mengun ruang sisi lengkung } \\
\text { taban dan mendeskripsikan data dalam bentuk }\end{array}$ & 37,50 \\
\cline { 2 - 3 } & Ukuran pemusatan data & 43,75 \\
\cline { 2 - 3 } & Peluang & 10,42 \\
\hline \multirow{2}{*}{} & & 20,83 \\
\hline
\end{tabular}

Berdasarkan data pada Tabel 3, tidak ada satu materipun yang dikuasai lebih dari $75 \%$ mahasiswa. Hanya ada dua materi yang dikuasai lebih dari atau sama dengan 50\% mahasiswa, yaitu 1) lingkaran dan 2) sistem persamaan linear dua variabel. Enam belas materi yang lain hanya dikuasai kurang dari 50\% mahasiswa. Materi dengan tingkat penguasaan paling rendah (dibawah $10 \%)$ ada dua, yaitu 1) kesebangunan dan kekongruenan dan 2) persamaan garis lurus.

Tabel 4. Penguasaan Materi SMA

\begin{tabular}{|l|l|l|}
\hline Bidang & \multicolumn{1}{|c|}{ Lingkup Materi } & Penguasaan (\%) \\
\hline \multirow{4}{*}{ Aljabar } & Bentuk pangkat, akar, dan logaritma & 0,00 \\
\cline { 2 - 3 } & $\begin{array}{l}\text { Fungsi, komposisi fungsi, fungsi invers, grafik } \\
\text { fungsi }\end{array}$ & 28,13 \\
\cline { 2 - 3 } & Persamaan fungsi kuadrat & 6,25 \\
\cline { 2 - 3 } & Program linear & 12,50 \\
\cline { 2 - 3 } & matriks & 10,42 \\
\cline { 2 - 3 } & Barisan dan deret aritmatika dan geometri & 13,54 \\
\hline
\end{tabular}


ISSN 2089-8703 (Print) Vol. 6, No. 3 (2017)

ISSN 2442-5419 (Online)

\begin{tabular}{|c|l|l|}
\hline \multirow{4}{*}{ Kalkulus } & Limit fungsi aljabar & 35,42 \\
\cline { 2 - 3 } & Turunan fungsi aljabar & 31,25 \\
\cline { 2 - 3 } & Integral tentu dan tak tentu fungsi aljabar & 12,50 \\
\hline \multirow{4}{*}{\begin{tabular}{c} 
Geometri $\begin{array}{c}\text { dan } \\
\text { trigonometri }\end{array}$ \\
\cline { 2 - 3 }
\end{tabular}} & Perbandingan trigonometri & 4,17 \\
\cline { 2 - 3 } & Aturan sinus dan kosinus & 10,42 \\
\cline { 2 - 3 } & Kedudukan dan jarak dari titik, garis, dan bidang & 0,00 \\
\cline { 2 - 3 } & dua bidang & 0,00 \\
\cline { 2 - 3 } & Persamaan lingkaran dan garis singgung lingaran & 12,50 \\
\cline { 2 - 3 } & Transformasi geometri & 0,00 \\
\hline \multirow{5}{*}{ Statistika } & $\begin{array}{l}\text { Penyajian data dalam bentuk tabel, diagram, dan } \\
\text { grafik }\end{array}$ & 43,75 \\
\cline { 2 - 3 } & Ukuran pemusatan, letak, dan penyebaran data & 6,25 \\
\cline { 2 - 3 } & Kaidah pencacahan & 2,08 \\
\cline { 2 - 3 } & Peluang suatu kejadian & 20,83 \\
\hline
\end{tabular}

Berdasarkan data pada Tabel 4, tidak ada satu materipun yang dikuasai lebih dari $75 \%$ mahasiswa. Semua materi SMA hanya dikuasai kurang dari $50 \%$ mahasiswa. Tiga materi dengan penguasaan tertinggi (lebih dari 30\%) adalah materi: 1) penyajian data dalam bentuk tabel, diagram, dan grafik; 2) limit fungsi aljabar; dan 3) turunan fungsi aljabar. Sedangkan 4 materi dengan tingkat penguasaan yang paling rendah $(0 \%)$ adalah materi: 1$)$ bentuk pangkat, akar, dan logaritma; 2) kedudukan dan jarak dari titik, garis, dan bidang; 3) besar sudut antara garis dan bidang, serta antara dua bidang; 4) transformasi geometri.

\section{KESIMPULAN DAN SARAN}

Kesimpulan yang diperoleh dari hasil penelitian ini adalah sebagai berikut:

1. Rata-rata penguasaan materi matematika sekolah mahasiswa pendidikan matematika semester VI yaitu $22,50 \%$.

2. $94 \%$ mahasiswa hanya menguasai materi matematika sekolah pada rentang $0 \%-50 \%$.

3. Terdapat empat materi matematika SMA yang tingkat penguasaannya adalah $0 \%$ yaitu materi logaritma; kedudukan dan jarak dari titik, garis, dan bidang; besar sudut antara garis dan bidang, serta antara dua bidang; dan transformasi geometri.

Berdasarkan hasil tersebut, dapat disimpulkan bahwa penguasaan materi matematika sekolah mahasiswa pendidikan matematika semester VI sangat rendah. Hasil ini menunjukkan bahwa mahasiswa pendidikan matematika semester VI sebagai calon guru matematika belum memiliki kompetensi professional yang baik sebagaimana disyaratkan dalam UU Nomor 14 Tahun 2005.

Berdasarkan hasil penelitian dan kesimpulan yang diperoleh, diajukan beberapa saran sebagai berikut:

1. Perlu suatu usaha tambahan bagi program studi untuk meningkatkan penguasaan materi matematika sekolah mahasiswa.

2. Perlu peninjauan kembali mengenai kurikulum pada program studi untuk memasukkan materi perkuliahan yang dapat meningkatkan penguasaan materi matematika sekolah mahasiswa.

3. Perlu usaha yang serius dari para mahasiswa untuk mempelajari materi matematika sekolah sebagai 
bekal untuk melaksanakan Praktek Pengalaman Lapangan (PPL), Penelitian, dan ketika menjadi guru nanti setelah menyelesaikan perkuliahan.

\section{DAFTAR PUSTAKA}

Abdullah, S.S. 2015. Mahasiswa (Calon) Guru Matematika yang Profesional. Prosiding Seminar Nasional Matematika dan Pendidikan Matematika UNY, Hal. 721-726.

Hindarto, N., Wijayanto, dan Sugiyanto. 2016. Profil Kemampuan Dasar Materi Bidang Keilmuan Mahasiswa S2 Pendidikan IPA. Laporan Akhir Penelitian Unggulan Internal oleh DIPA Universitas Negeri Semarang: Semarang.

Marhamah. 2016. Kompetensi Profesional Guru Matematika. Jurnal Dosen Universitas PGRI Palembang Edisi 4. http://www.univpgri-palembang. ac.id/e_jurnal/index.php/prosiding /article/view/518 diakses 5 Maret 2017.

Maryono. 2016. Profil Pedagogical Content Knowledge (PCK) Mahasiswa Calon Guru Matematika Ditinjau dari Kemampuan Akademiknya.
Jurnal Review Pembelajaran Matematika. Vol. 1, No. 1, Hal 116.

Masril, P, R., Akmam, dan Irvan. 2013. Analisis Kemampuan Awal Mahasiswa Tahun Pertama Jurusan Fisika FPMIPA UNP. http://fisika. fmipa.unp.ac.id/wpcontent/uploads/ 2014/12/File10.pdf diakses 5 Maret 2017.

Pakaya, I.L.A. 2014. Deskripsi Kompetensi Mahasiswa Program Studi Pendidikan fisika dalam menyelesaikan soal-soal prediksi modifikasi ujian nasional mata pelajaran fisika. Skripsi: Gorontalo.

Permendiknas Nomor 16 Tahun 2007 tentang Standar Kualifikasi Akademik dan Kompetensi Guru.

Permendiknas Nomor 21 Tahun 2016 tentang Standar Isi Pendidikan Dasar dan Menengah.

Romadiastri, Y. 2012. Analisis kesalahan mahasiswa matematika dalam menyelesaikan soal-soal logika. Jurnal Phenomenon, Vol. 2, No. 1, Hal. 75-93.

Undang-undang Nomor 14 Tahun 2005 tentang Guru dan Dosen. 